\title{
Long-lived magmatism of the Peninsular Ranges batholith: An example of continental growth at subduction zones
}

\author{
MANUEL CONTRERAS-LÓPEZ, PHD ${ }^{1}$, LUIS A. \\ DELGADO-ARGOTE ${ }^{1}$, BODO WEBER ${ }^{2}$, XÓCHITL G. \\ TORRES-CARRILLO ${ }^{3}$, DIRK FREI ${ }^{4}$ AND DORIS K. \\ GÓMEZ-ALVAREZ ${ }^{1}$
}

${ }^{1}$ Center for Scientific Research and Higher Education of Ensenada

${ }^{2}$ Centro de Investigación Científica y de Educación Superior de Ensenada BC (CICESE)

${ }^{3}$ Autonomous University of Sinaloa

${ }^{4}$ University of the Western Cape

Presenting Author: contreras.geo@hotmail.com

The Peninsular Ranges batholith (PRB) is a segment of the North American Cordillera that provides a long record of subduction-related magmatism (177-92 Ma). However, such record is fragmented and displays broad petrologic variations, difficult to integrate into a coherent geologic evolution history. Here, we present a petrogenetic study of Cretaceous plutons and Jurassic host rocks of the southern PRB in a profile perpendicular to the paleotrench (SW-NE). We propose a continuous magmatic activity from Middle Jurassic to Late Cretaceous and a continental growth model for NW Mexico during that period. The western zone, on the paleotrench side, consists of a Middle Jurassic-Early Cretaceous (166-140 Ma) island arc rocks with sedimentary rocks of intra-arc and oceanic marginal basins. The Jurassic sequence was intruded by basic to intermediate plutonic rocks (105-100 Ma) showing $\varepsilon \mathrm{Sr}_{\mathrm{t}}$ (average $-3.6, \mathrm{n}=6), \varepsilon \mathrm{Nd}_{\mathrm{t}}$ (average $+3.3, \mathrm{n}=6$ ), and $\varepsilon \mathrm{Hf}_{\mathrm{t}}$ values (average $+6.0, \mathrm{n}=3$ ) that suggest an origin from mantle-derived melts with a low degree of contamination. The nearly flat rare earth elements (REE) patterns in these rocks suggest that fractionation occurred under the stability field of plagioclase. More than 200 $\mathrm{km}$ from the paleotrench, the eastern zone is dominated by granitic and granodioritic rocks (100-92 Ma). The $\varepsilon_{\mathrm{Sr}_{\mathrm{t}}}$ (average $-4.7, \mathrm{n}=9), \varepsilon \mathrm{Nd}_{\mathrm{t}}($ average $+0.8, \mathrm{n}=9)$, and $\varepsilon \mathrm{Hf}_{\mathrm{t}}$ (average $+2.6, \mathrm{n}$ $=3$ ) values in the acidic rocks suggest a mantle-derived melt genesis with increased contamination. Most of these rocks display a depleted-HREE pattern suggesting differentiation at deep crustal reservoirs under the influence of garnet. The Jurassic-Cretaceous (166-92 Ma) magmatism of the southern PRB displays an $\varepsilon \mathrm{Sr}_{\mathrm{t}}$ vs. $\varepsilon \mathrm{Nd}_{\mathrm{t}}$ correlation trend indicating progressive contamination of mantle-derived magmas with a recycled crust. $\mathrm{Sr}-\mathrm{Nd}$ and $\mathrm{Nd}-\mathrm{Hf}$ isotopic mixing curves suggest the assimilation of the metasedimentary Triassic basement of NW Mexico instead of the Precambrian basement. We consider the geochemical, isotopic, and temporal variation of the PRB indicative of natural heterogeneities along the axis of a longlived arc system. 